D\&D-45228

Revision 0

\title{
Effect on 105KW North Wall due to Addition of Filtration System
}

Prepared for the U.S. Department of Energy

Assistant Secretary for Environmental Management

Contractor for the U.S. Department of Energy

under Contract DE-AC06-08RL14788

\section{CH2MHILL}

Plateau Remediation Company

P.O. Box 1600

Richland, Washington 99352 
D\&D-45228

Revision 0

EDC \#: PRC-EDC-10-45229

\section{Effect on 105KW North Wall due to Addition of Filtration System}

Document Type: CN

Program/Project: 100K D\&D

C. S. Cho

CH2M HILL Plateau Remediation Company

Date Published

March 2010

Prepared for the U.S. Department of Energy

Assistant Secretary for Environmental Management

Contractor for the U.S. Department of Energy

under Contract DE-AC06-08RL14788

CH2MHILL

Plateau Remediation Company

P.O. Box 1600

Richland, Washington

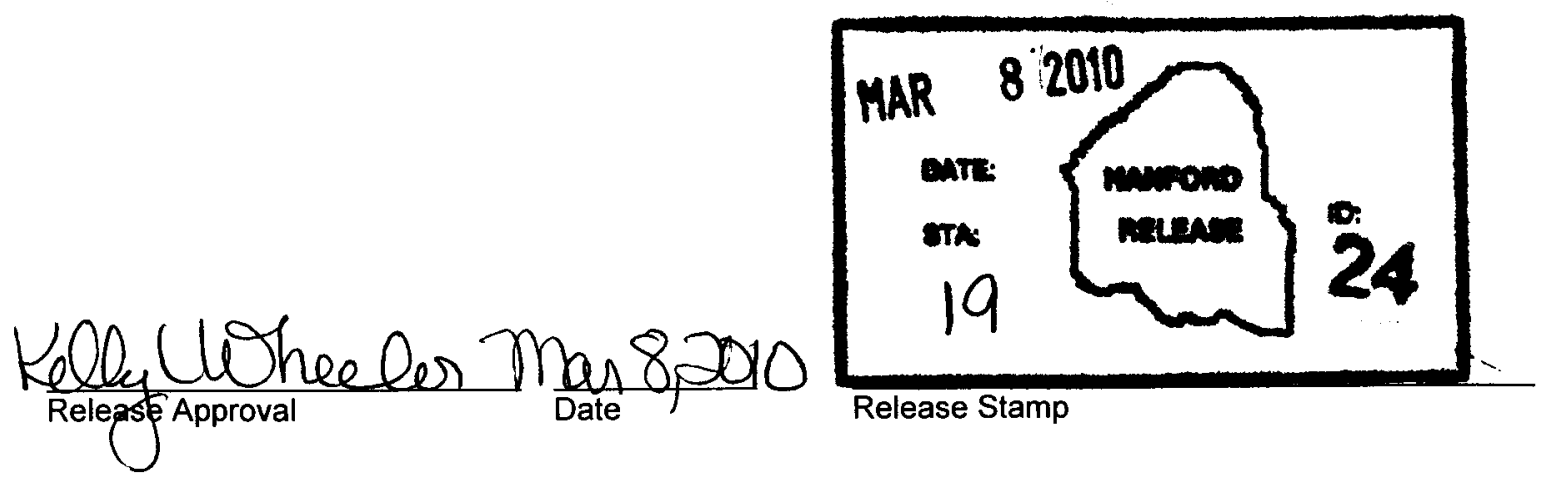


D\&D-45228

Revision 0

TRADEMARK DISCLAIMER

Reference herein to any specific commercial product, process, or service by trade name, trademark, manufacturer, or

otherwise, does not necessarily constitute or imply its

endorsement, recommendation, or favoring by the United

States Government or any agency thereof or its contractors or subcontractors.

This report has been reproduced from the best available copy.

Printed in the United States of America

Total Pages: 
D\&D-45228

Rev 0

\section{CHPRC: D\&D-45228}

EDC : PRC-EDC-10-45229

Title: Effect on 105KW North Wall due to Addition of Filtration

CHPRC D\&D Projects is adding three filtration systemson two 1-ft concrete pads adjacent to the north side of existing $\mathrm{KW}$ basin building. Attached calculation (Calculation Number 302170-C-1) to this EDC provides qualitative assessment of effect of this addition onto the basin wall. 
D\&D-45228

Rev 0

\section{Calculation Cover Sheet and Revision Summary}

\section{Section 1: Identification}

1. Project Identifier

ARES 0846401.30
2. Modification Description Title/Subject

Effect on 105KW North Wall due to Addition of Filtration System
3. Page $i$ of ii

4. Use of Form

[ $\mathrm{x}$ ] Calculation [ ] Engineering Analysis [ ] Software Installation [ ] Technical Basis [ ] Other

5. Job Title

100K Utility Upgrades (ARRA)

6. WBS Number N/A

8. Calculation Number 302170-C-1

12. Independent Verification Required?

[ ] Yes

$[\mathrm{X}]$ No

Section 2: Preparation, Review, and Approval

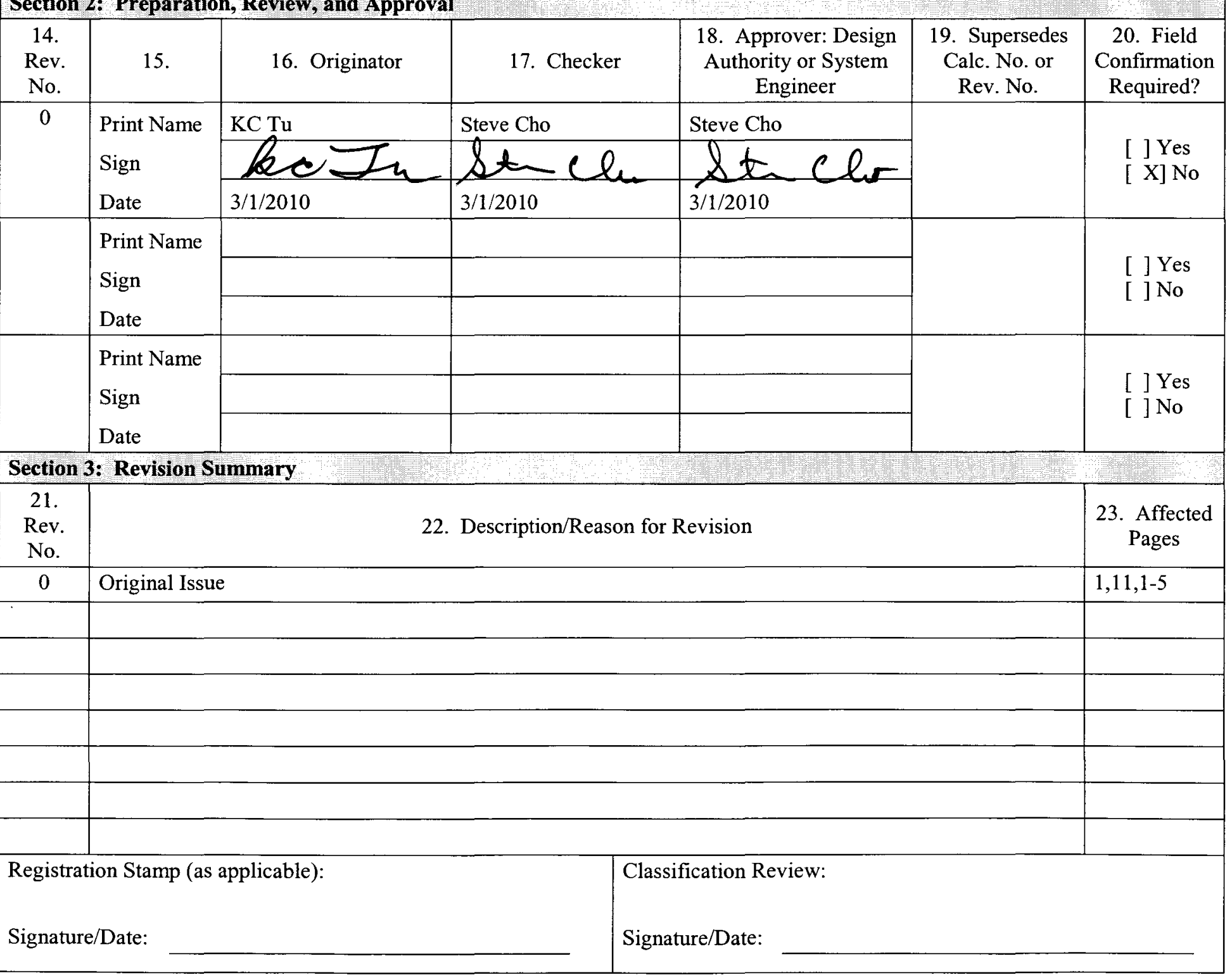

\section{Department/Organization CHPRC D\&D}

\begin{tabular}{l|l|l}
$\begin{array}{l}\text { 9. Affected Building Numbers } \\
105 \mathrm{KW}\end{array}$ & $\begin{array}{l}\text { 10. Room } \\
\text { Basin }\end{array}$ & $\begin{array}{l}\text { 11. Floor } \\
\text { North Wall }\end{array}$
\end{tabular}

13. Performance Category (PC)

$\left[\begin{array}{ll}0 & {[}\end{array}\right]$

$[$ ] 2

[ ] 3

$[X] N / A$

$[1] 3$




\section{Calculation/Technical Basis Sheet}

\section{Section 1: Identification}

1. Project Number

ARES 0846401.30

4. Calculation Number

302170-C-1
2. Modification Description Title/Subject

Effect on 105KW North Wall due to Addition of Filtration System
3. Page ii of ii

5. Rev. No.

\section{Section 2: Scope, Objective, Method, Assumptions, Technical Basis}

6. Scope and Objective

CHPRC D\&D Projects is adding three filtration system on two 1-ft concrete pads adjacent to the north side of existing KW Basin building. Based on the review of design information available for $105 \mathrm{KW}$ basin substructure, this analysis is prepared to provide qualitative assessment of effect of added pads and filtration system dead weight and seismic load on the north wall.

\section{Method}

Hand calculations with the assistance of MathCad Version 14.0 Program.

8. Assumptions and Technical Basis

HVAC Filtration System weights 15,000 pound each. $0.20 \mathrm{~g}$ Seismic load (p. 1-7 of Ref. 2)

\section{Section 3: Design Inputs/References}

\begin{tabular}{|l|l|}
\hline \multicolumn{1}{|c|}{ 9. Ref. No. } & \multicolumn{1}{|c|}{ 10. Inputs/References (with Revision and/or Date or Source) } \\
\hline 1 & Drawing H-1-91482, Rev.0A, "105KW HVAC Equipment foundation Plan". \\
\hline 2 & $\begin{array}{l}\text { WHC-SD-NR-SA-024, Rev. 0, "105-KE/105-KW Irradiated Fuel Storage Basin Seismic Qualification Final", by B. } \\
\text { V. Winkel, Dec 27, 1991. }\end{array}$ \\
\hline 3 & $\begin{array}{l}\text { "Foundation Engineering Handbook", 2nd Ed. Edited by Hsai-Yang Fang, Van Nostrand Reinhold, New York, } \\
1991 .\end{array}$ \\
\hline Section 4: Conclusions
\end{tabular}

Following analysis demonstrates that the newly added filtration units and their pads do not exceed the structural capacity of existing wall. The calculation shows that the total bending moment on the north wall due to newly added filtration units and pads including seismic load is $82.636 \mathrm{ft}-\mathrm{kip} / \mathrm{ft}$ and is within the capacity of wall which is $139.0 \mathrm{ft}-\mathrm{kip} / \mathrm{ft}$. 


\section{PURPOSE and OBJECTIVE:}

CHPRC D\&D Projects is adding three filtration system on two 1-ft concrete pads adjacent to the north side of existing KW Basin building. This analysis is prepared to provide qualitative assessment based on the review of design information available for $105 \mathrm{KW}$ basin substructure.

In the proposed heating, ventilation and air conditioning (HVAC) filtration pad designs a $2 \mathrm{ft}$ gap will be maintained between the pads and the north end of the existing $105 \mathrm{KW}$-Basin building. Filtration Skids \# 2 and \#3 share one pad. It is conservative to evaluate the \#2 and \#3 skid pad for the wall assessment. Figure 1 shows the plan layout of the 105KW basin site and the location of the pads for the filtration system or HVAC skids. Figure 2 shows the cross-section elevation view of the pad. The concrete pad Drawing H-1-91482 directs the replacement of the existing 8 " concrete pad with two new 1 -ft think pads. The existing 8" pad is separated from the $105 \mathrm{KW}$ basin superstructure by an expansion joint of only half an inch. The concrete pad Drawing H-1-91482 shows the gap between the new proposed pads and the north wall and any overflow pits and sumps is 2 -ft.

\section{CONCLUSIONS:}

Following analysis demonstrates that the newly added filtration units and their pads do not exceed the structural capacity of existing wall. The calculation shows that the total bending moment on the north wall due to newly added filtration units and pads including seismic load is $82.636 \mathrm{ft}-\mathrm{kip} / \mathrm{ft}$ and is within the capacity of wall which is 139.0ft-kip/ft. 
Subject: Effect on 105KW North Wall due to Addition of Filtration System Location: Building 105KW

Originated By: KC Tu Roof Thate: $3 / 10$ Checked By: Steve Cho, StC Le date: 3/10

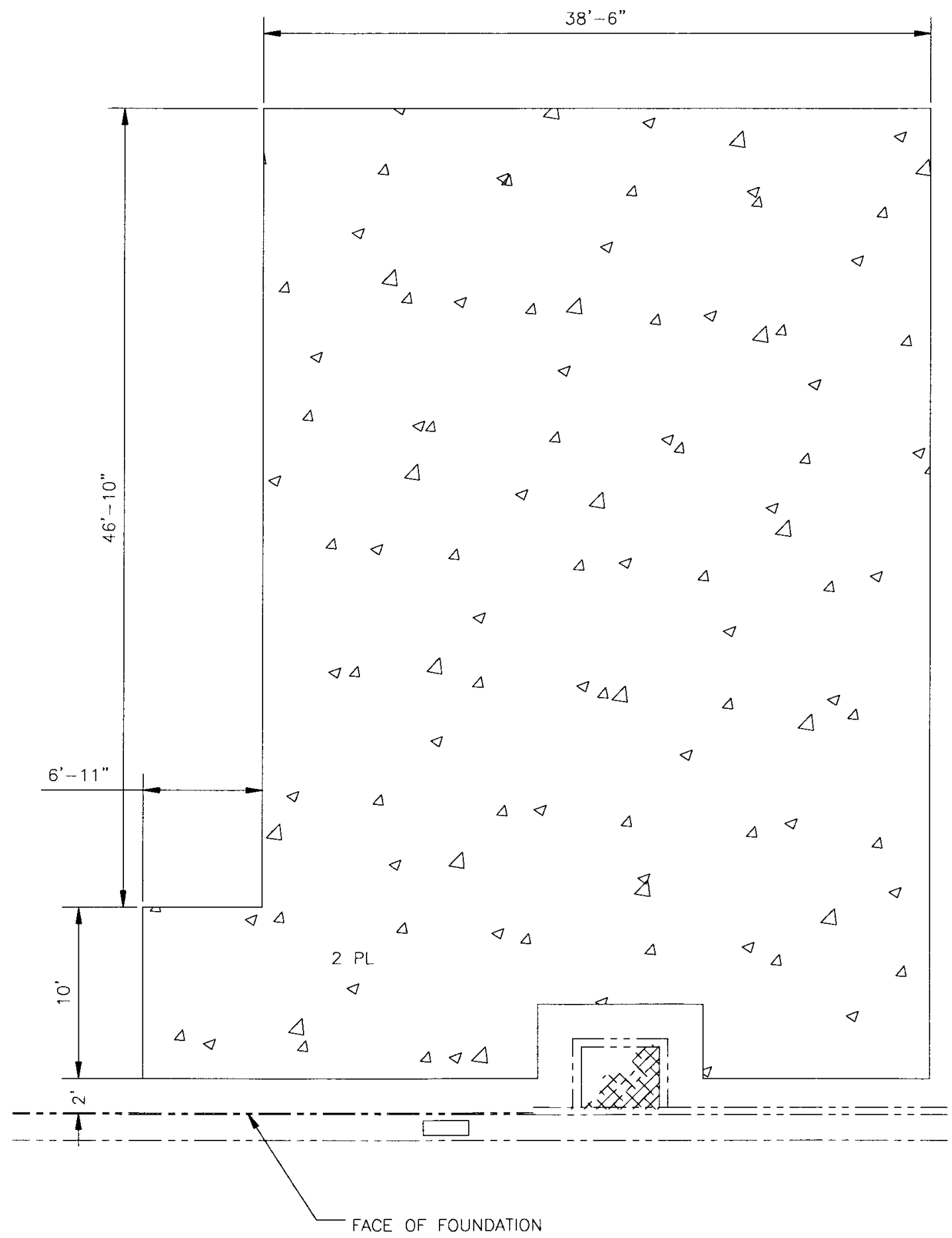

Figure 1 HVAC Equipment Pad 


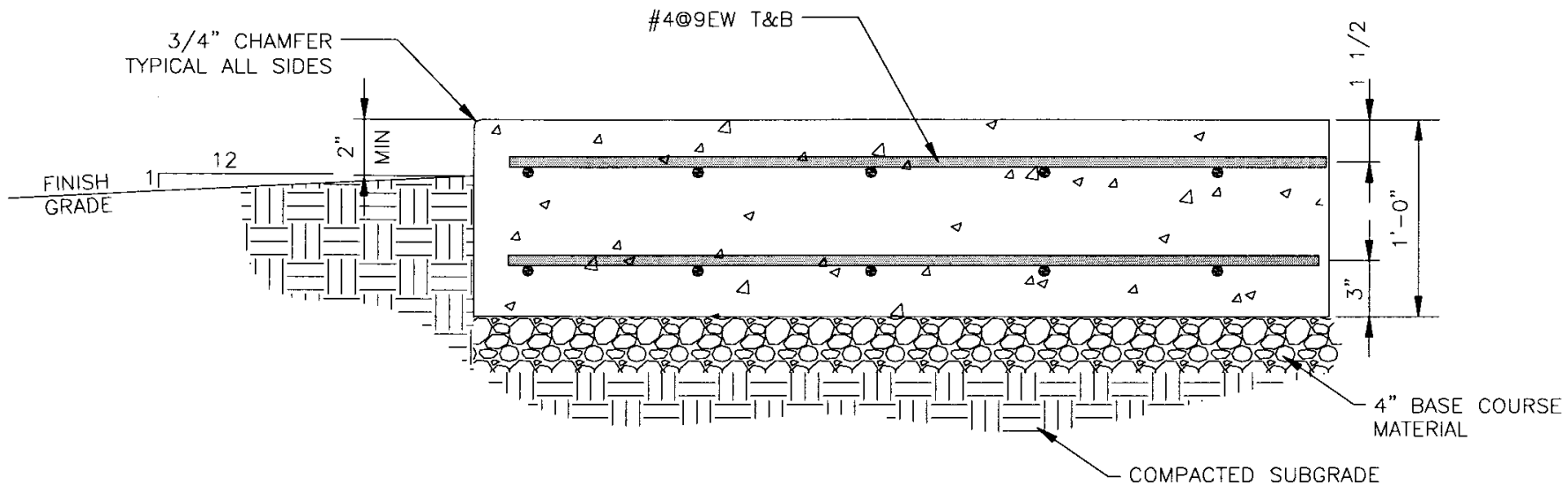

Figure 2 Pad Section

\section{CALCULATION:}

\begin{tabular}{|c|c|}
\hline $\mathrm{H}:=20.75 \cdot \mathrm{ft}$ & 105-KW Basin wall height (p.1-2 of Ref.2) \\
\hline $\mathrm{EQ}:=0.2$ & $\begin{array}{l}\text { seismic load see p.1-7 of Ref.2 (The equipment } \\
\text { and rigid. No amplification factor is needed) }\end{array}$ \\
\hline $\mathrm{W}:=30 \cdot \mathrm{kip}$ & HVAC equipment weight (units $2 \& 3$ ) \\
\hline$a:=38 \cdot f t+6 \cdot i n$ & concrete pad width (parallel to the wall) \\
\hline $\mathrm{b}:=56 \cdot \mathrm{ft}+10 \cdot \mathrm{in}$ & concrete pad length (perpendicular to the wall) \\
\hline $\mathrm{d}:=\mathrm{ft}$ & concrete pad depth \\
\hline $\mathrm{e}:=2 \cdot \mathrm{ft}$ & gap between wall and pad \\
\hline$\rho_{\text {conc }}:=150 \cdot \mathrm{pcf}$ & concrete density \\
\hline$\rho_{\text {soil }}:=110 \cdot \mathrm{pcf}$ & soil density \\
\hline
\end{tabular}

$p:=\frac{W}{a \cdot b}+\rho_{\text {conc }} \cdot d-\rho_{\text {soil }} \cdot(d-2 \cdot$ in $)=72.044 \cdot p s f$

soil pressure underneath the pad ( 2 " above grade)

$\mathrm{p}_{\mathrm{e}}:=\left(1+\mathrm{EQ} \cdot \frac{2}{3}\right) \cdot \mathrm{p}=81.65 \cdot \mathrm{psf}$ add vertical seismic load $(2 / 3$ of $0.2 \mathrm{~g})$ to soil pressure 
lateral soil pressure due to the equipment, pad, and vertical seismic load [eq. (6.17) of Ref. 3]

$\Delta p_{h}=\frac{2 \cdot p_{e}}{\pi} \cdot(\alpha-\sin (\alpha) \cdot \cos (\alpha+2 \cdot \delta))$

$\delta(\mathrm{h}):=\operatorname{atan}\left(\frac{\mathrm{e}}{\mathrm{h}}\right)$

$\alpha(h):=\operatorname{atan}\left(\frac{e+b}{h}\right)-\delta(h)$

$\Delta \mathrm{p}(\mathrm{h}):=\frac{2 \cdot \mathrm{p}}{\pi} \cdot(\alpha(\mathrm{h})-\sin (\alpha(\mathrm{h})) \cdot \cos (\alpha(\mathrm{h})+2 \cdot \delta(\mathrm{h})))$

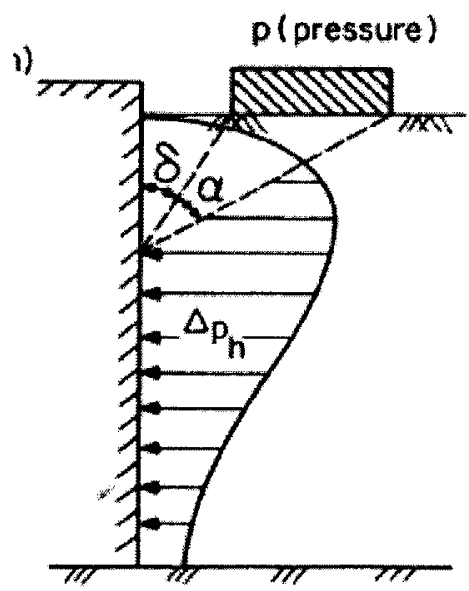

$\mathrm{h}:=\mathrm{ft}, 1.5 \cdot \mathrm{ft} . . \mathrm{H}$

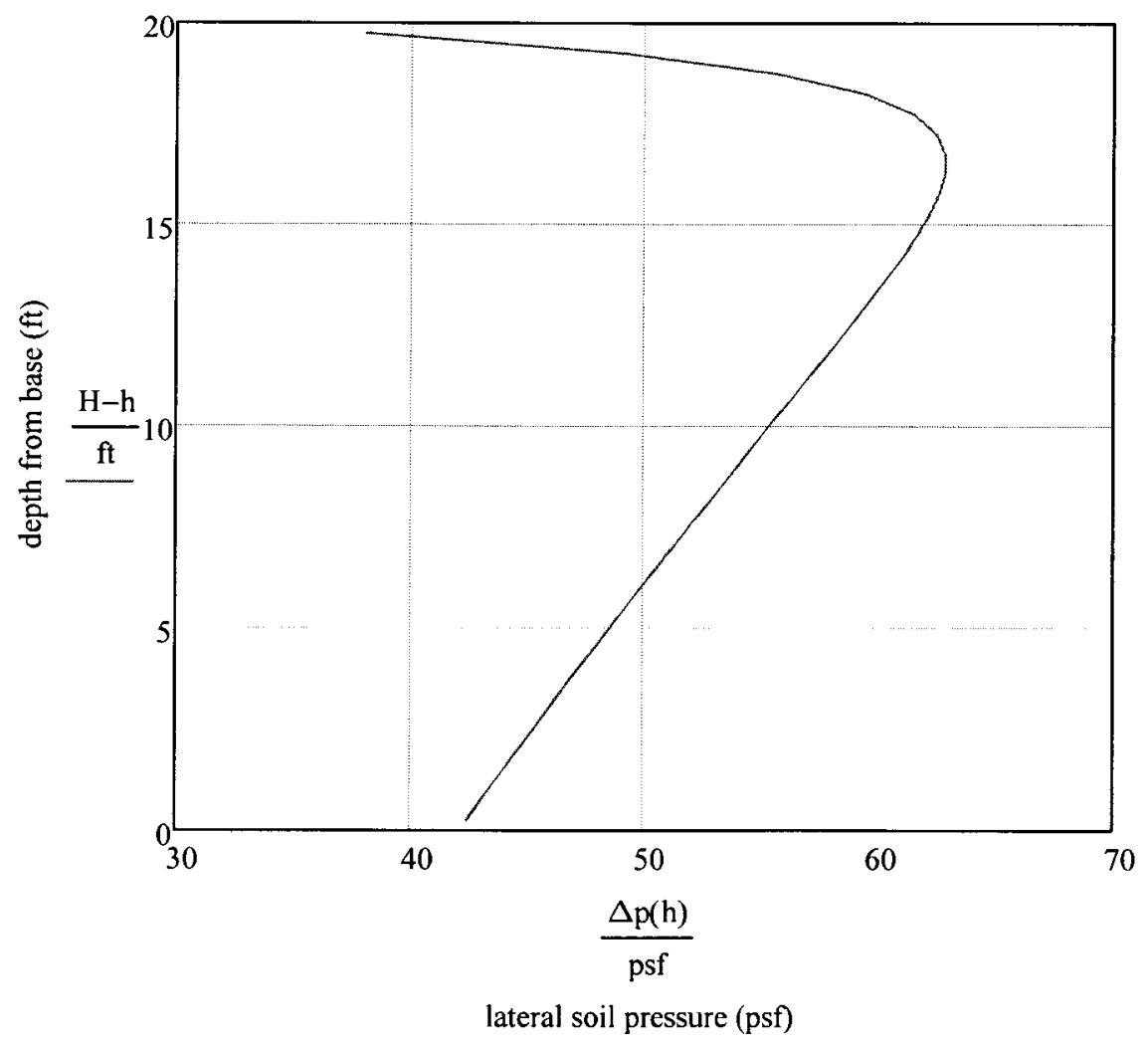

LATERAL SOIL PRESSURE DISTRIBUTION 


\section{Demand moment at exterior wall base}

Assuming the wall is fixed at bottom, the moments at the bottom

$$
\begin{aligned}
& \mathrm{M}_{\text {soil }}:=\int_{0 \cdot \mathrm{ft}}^{\mathrm{H}} \Delta \mathrm{p}(\mathrm{h}) \cdot(\mathrm{H}-\mathrm{h}) \mathrm{dh}=11.478 \cdot \mathrm{kip} \quad \text { due to increased lateral soil pressure } \\
& \mathrm{M}_{\mathrm{HVAC}}:=\mathrm{EQ} \cdot \mathrm{p}_{\mathrm{e}} \cdot \mathrm{b} \cdot \mathrm{H}=19.258 \cdot \mathrm{kip} \quad \text { due to } E Q \text { of equipment and pad } \\
& \mathrm{M}_{\text {exist }}:=51.9 \cdot \mathrm{kip} \\
& \mathrm{M}_{\text {total }}:=\mathrm{M}_{\text {soil }}+\mathrm{M}_{\mathrm{HVAC}}+\mathrm{M}_{\text {exist }}=82.636 \cdot \frac{\mathrm{ft} \cdot \mathrm{kip}}{\mathrm{ft}} \quad \text { total moment with HVAC and pad } \\
& <\quad 139.0 \cdot \frac{\mathrm{ft} \cdot \mathrm{kip}}{\mathrm{ft}} \quad \text { wall capacity (Table 9-3 on p.9-8 of Ref.2) OK }
\end{aligned}
$$

